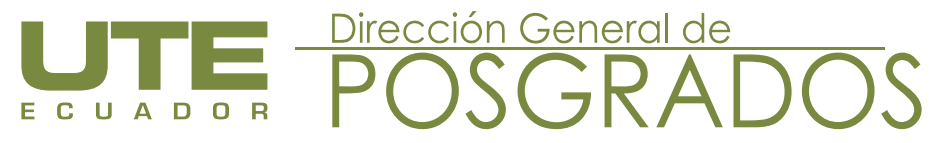

\title{
LA MUY ANTIGUA, MUY QUERIDA Y JAMÁS OLVIDADA VIRGEN DE LA MANO SANTA
}

\author{
Juan Carlos Riofrío Martínez-Villalba \\ 'Universidad de Los Hemisferios, Quito - Ecuador, juancarlosr@uhemisferios.edu.ec
}

Recepción / Received: 20, 08, 2014

Aceptación / Accepted: 13, 11, 2014

Publicado / Published: 12, 12, 2014

\section{RESUMEN}

El presente trabajo recoge la historia de un cuadro de la "Virgen de la Mano Santa", del cual el pueblo guayaquileño fue muy devoto por cuatro siglos, hasta 1902, cuando un gran incendio en la ciudad lo redujo a cenizas. Alrededor de la imagen se generaron historias, leyendas, devociones, etc. que la ciudad perdió en el mencionado fuego. Pese a ello, actualmente se está intentando rescatar la historia de la imagen, como se comenta en este artículo de corte más histórico, que hace uso de fuentes españolas y americanas. Se trata de un estudio histórico, expuesto de manera cronológica. Luego de una breve introducción, se analiza la historia de la imagen guayaquileña desde su creación en el siglo XVI, hasta su desaparición en 1902, y los esfuerzos hechos en el siglo XX por rescatarla, para terminar con una breve conclusión.

\section{PALABRAS CLAVE}

Cultura guayaquileña, devociones marianas, Historia de Guayaquil, imágenes desaparecidas, tradiciones ecuatorianas.

\begin{abstract}
This paper presents the story of a painting of the "Virgin of the Holy Hand", which the people of Guayaquil were very devoted for four centuries, until 1902, when a major fire in the city reduced it to ashes. Around the image were generated stories, legends, devotions, etc. that the city lost in that fire. Despite this, we are currently trying to rescue the history of the image, as discussed in this article of a more historical point of view, which makes use of Spanish and American sources. This is a historical study, chronologically exposed. After a brief introduction, the history of the image is analyzed from its creation in the sixteenth century to its disappearance in 1902, and the efforts made to rescue it in the last century. The paper ends with a brief conclusion.
\end{abstract}

\section{KEYWORDS}

Guayaquil Culture, Marian Devotions, History of Guayaquil, Images Disappeared, Ecuadorian traditions. 


\section{INTRODUCCIÓN}

La Virgen de la Mano Santa ha sido la imagen más venerada en la historia de Guayaquil. Esta devoción llegó a la ciudad desde su misma fundación; vino desde la otra orilla del Atlántico, con fama de reina y de obradora de grandes milagros, para acompañar al pueblo por más de tres siglos. Lamentablemente, las llamas del terrible incendio de 1902 hicieron ceniza y humo el cuadro que se veneraba y hasta la iglesia donde colgaba. El presente trabajo analiza la historia de esta imagen perdida, desde su creación en el siglo XVI hasta su desaparición en 1902, y los esfuerzos hechos en el siglo XX por rescatarla.

La perspectiva del análisis es histórica, y su exposición se hace de forma cronológica. La investigación que ha durado más de diez años, actualmente se enmarca dentro de la línea de investigación "Diálogo intercultural y civilizatorio contemporáneo" y del proyecto "Factores detonantes de la evolución de la cultura ecuatoriana" de la Universidad de Los Hemisferios. Para el efecto se han consultado fuentes ecuatorianas y españolas, estudios, fotos y testimonios que fueron recogidos por el autor en Guayaquil, Quito e Iruz (Cantabria, España).

\section{LA DEVOCIÓN A LA VIRGEN MORENA AL OTRO LADO DEL MAR}

La historia de la Virgen guayaquileña comienza en el montañoso y húmedo valle de Toranzo, en la Cantabria, al norte de la península lbérica. No se sabe bien desde cuándo se plantó en medio de este valle un hospital, que sería el que después albergaría la devota imagen de Iruz. Las primeras noticias que tenemos de este edificio son confusas y remotas. Hoy cuelga en el lugar una lápida que dice: "Ovechus port in honorem S. Crucis a rei in coelo conspectae dum / cum mauris praeliretur / Pro Ildefonsi Rege / Hospicum hocce condere decrevit / A era DCCLXXII", cuya traducción viene a ser: "Oveco, para honor de la Santa Cruz mandó se edificara un hospital, ya que al estar luchando con otros soldados, contra los moros, vio aparecerse esta santa señal en el cielo. Peleaba a las órdenes del Rey Alfonso en la era de 772" (año de 734). La mencionada placa ha sido puesta en duda por los estudiosos, porque en tal fecha no reinó ningún Alfonso. De todas formas, se acepta que el texto pudo haber sido mal interpretado o leído. Otro dato a tener en cuenta es que esa lápida no ha llegado a nosotros; la que ahora cuelga en el Santuario de Iruz se la colocó en recuerdo de la anterior (González Echegaray, 1992, p. 96).
De fiarnos del año transcrito, el hospital se habría fundado cuando el ducado de Cantabria comenzaba a defenderse del invasor moro. Allá por el año 714, la tropa musulmana arremetió en el lado sur del ducado. Conforme avanzaba, los cántabros habrían tenido que replegarse al norte, sufriendo grandes bajas. Es natural que entonces desearan levantar un edificio para hospedar y atender a los refugiados, resultando espléndido asentarse en medio del valle de Toranzo. La mención del rey Alfonso habría sido producto de una inadecuada asociación hecha por quien redactó la placa muchos años más tarde. Faltaría por explicar por qué el nombre de Alfonso sonaba tanto, para poder crear una confusión de esta naturaleza.

Otros datos a tomar en cuenta son las numerosas escrituras protocolarias que dan fe de que en el siglo XVI existía un hospital en Iruz y los adornos de veneras o conchas pegados a la antiquísima torre octogonal, que recuerdan el paso de la ruta jacobea por este santuario y por su hospital de peregrinos. Como se sabe, Santiago de Compostela surge con el hallazgo de las reliquias del Apóstol, hecho producido en el año 812. El Rey de Asturias, Alfonso II apodado "el Casto" (c. 760-842), viajará con su corte al sepulcro convirtiéndose en el primer peregrino oficial, y será él quien construya una pequeña iglesia para el Santo. A partir de ahí las peregrinaciones se multiplicarán, incentivadas por la orden de Cluny y por los reyes cristianos, que harán generosas donaciones a sus monasterios. De esta manera la enigmática lápida pudo ser elaborada en el siglo IX, y el rey Alfonso sería el Rey de Asturias. Explicado el tema del nombre, resultaría aún necesario reconocer un defecto en el punto de la fecha, que no sería "DCCLXXII" (772), sino "DCCCLXXII" (872), año que cuadra mejor con lo explicado.

En todo caso lo cierto es que, para el siglo XIII, en ese lugar surgió la devoción a una nueva imagen que acababa de tallarse. Según los estudios, la talla de Nuestra Señora del Soto-Iruz data de este siglo. Se trata de una mujer coronada, sentada en un trono. Sobre su pierna izquierda se sienta el Niño, que también lleva corona y gobierna el universo, representado en un globo que sujeta en su mano izquierda'. Ambos personajes bendicen a la humanidad con la mano derecha ${ }^{2}$, cosa que el Niño hace con dos

1 En la época, el globo no representaba el globo terráqueo, pues casi toda la gente pensaba que la Tierra era plana. El universo solía representarse como una esfera celeste, siguiendo el modelo que diseñó Eratóstenes, es decir, la Esfera Armilar.

2 En cuanto a la mano del Niño, es indiscutible. Sin embargo, la mano derecha de la Virgen ha recibido varias interpretaciones. Por ejemplo, se ha dicho que "en la mano derecha llevaba algo que posteriormente le fue quitado variando su postura, que se cierra hacia dentro" (González Echegaray, 1992, p. 98). Lo más común es que las vírgenes hieráticas de la época llevaran en la mano derecha un globo (como la Virgen de Monserrat, de Castejón y del Camino de Ena, del s. XII; o las de Ginestarre, de Rañín y de Valdefresno del s. XIII), pero también hay algunas con un cetro, como la de la Merced, o un frasco, o flor (como la Virgen del Castillo del s. XII). Más tarde será más común poner flores, lirios, cadenas, rosarios, banderas, escapularios, etc. en la mano de la Señora. A veces llevaban las dos manos abiertas sin nada, como en Nuestra Señora de los Ángeles de Villanúa de siglo Xl, para presentar al Niño a las gentes, o en actitud orante o protectora. Si habríamos de poner algo a la Virgen, sería un cetro o una flor, pues el globo ya lo tiene el Niño. 
dedos alzados, que significan su humanidad y su divinidad, mientras los otros tres dedos recogidos simbolizan las tres Personas de la Santísima Trinidad ${ }^{3}$. La escultura es mucho más expresiva y detallada que las tallas románicas de la Virgen del siglo XII, lo que la ubica en la transición entre el románico y el gótico: su mirada es más maternal, con cejas arqueadas, la postura algo más holgada, menos hierática que las tallas anteriores; lleva túnica estofada y velo que cae en zig-zag a ambos lados de la cara. Su color primitivo fue "muy moreno" (cfr. González Echegaray, 1992, p. 98), aunque después recibió numerosos repintes. Este tipo de imágenes representan la Sedes Sapientiae, la Sede de la Sabiduría.

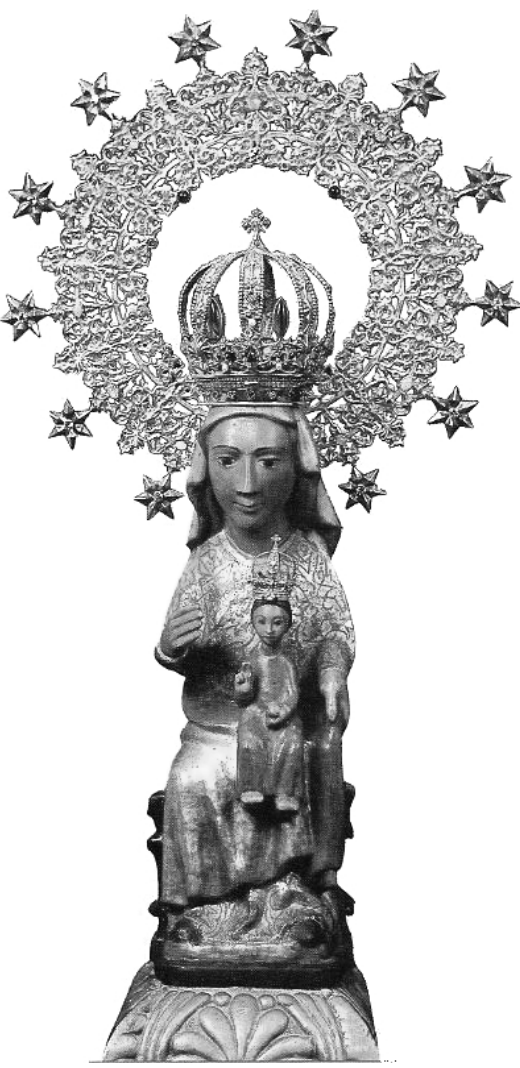

Figura $N^{\circ} 1$. Virgen antigua

La imagen acompañó las benéficas obras que se realizaban en el hospital de peregrinos. A ella acudían con gran fervor los enfermos y desvalidos de esta vida, buscando aquella ayuda que ya en la tierra ninguno podía dar. Pronto comenzaron a caer las gracias del cielo, la imagen comenzó a prodigar milagros grandes y chicos. Su devoción terminó traspasando los límites del valle de Toranzo y se instituyó la fiesta a la Virgen del Soto el 5 de agosto de cada año.

Fue lógico entonces que los vecinos desearan construir una casa más grande para su Reina. Desde 1570 se pusieron manos a la obra y, tras recaudar los fondos necesarios

3 Este es el significado cristiano del símbolo, muy anterior al símbolo de victoria que procede de las guerras entre franceses e ingleses del siglo $X V$. Tampoco es el significado que el mundo pagano daba a la expresión, donde los dos dedos significaban —-según algunos estudiosos - el auxilio y la fuerza, que eran asociados particularmente con Osiris y Horus: e primero representa la justicia divina y el segundo, el Espíritu, el Mediador. Cfr. Cooper, 1988 mediante generosas donaciones, se construyó el edificio más bonito y grande del lugar. Habrán participado en la empresa las familias más pudientes, como los Ceballos, los Quevedo y los Bustamante, junto a otras más modestas como los Castro y los Grijuela. Hoy tenemos prueba de algunas de sus aportaciones. De ese templo solo ha llegado hasta nosotros la hermosa torre octogonal construida hacia el año $1573^{4}$ bajo los nuevos cánones artísticos_-, que sigue coronando la fachada y que fue emblemática en la época barroca. Durante su primera época la iglesia y el hospital de peregrinos dependieron de dos curas beneficiados (González Echegaray, 1992, p. 96).

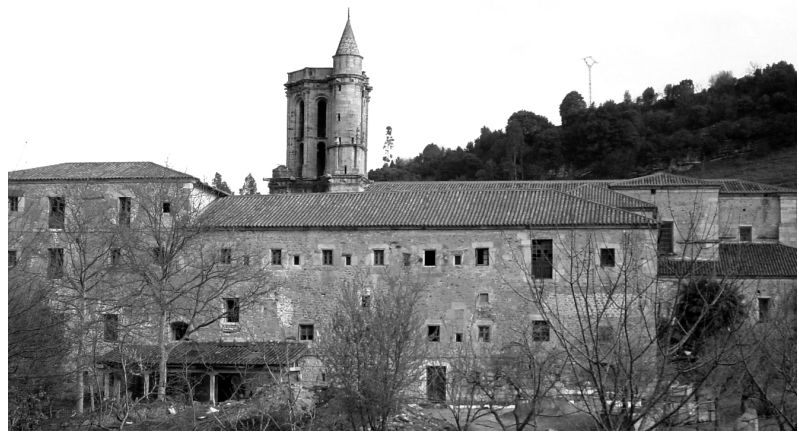

Figura $\mathrm{N}^{\circ}$ 2. Torre y convento.

Los frailes de San Francisco, que desde hacía varios siglos se habían ido estableciendo en las villas de la Costa (como sucedió en Castro Urdiales, Santander, Laredo y San Vicente de la Barquera) inician su incursión hacia el interior de La Montaña, y fundan en 1518 un convento en Reinosa. Años más tarde llegaron al fértil lugar llamado El Soto, junto al río Pas, y en 1608 tomaron posesión de templo de Iruz. Sobra decir que ellos no solo acogieron la devoción que se tenía a la Santísima Virgen, sino que, animados por las directrices del Concilio de Trento, la promovieron y aumentaron.

Como en otros santuarios, adornan las tapias de este numerosísimos exvotos colgados para agradecer los extraordinarios favores dispensados por celestial Señora. Entre ellos, se certifica el ocurrido a Juan de la Llama, que se libró de la muerte el 22 de enero del 1609 en la barra de Suances ${ }^{5}$, donde naufragó con dieciocho compañeros más. Encomendándose a la Virgen del Soto, asido a un remo, Juan permaneció por mucho tiempo flotando sobre las aguas sin saber nadar, hasta que le recogió una barca. Entre toda la tripulación fue el único que se salvó de ahogarse.

$4 \quad$ La torre marca un hito importante entre la tradición gótica y la estética barroca, que predominará a partir de este momento en la región. En su remate se encuentra grabada una fecha: 1573

$5 \quad$ La barra de Suances, ubicada en la desembocadura al mar, tiene el problema de entrada y salida en la ría de San Martín, que aún hoy sigue ocasionando numerosos accidentes. Entre otros problemas tiene el de la escasez de calado, donde cualquier golpe de mar amenaza con llevar a los barcos contra los espigones. Ello ha supuesto incluso el cierre del Puerto de Requejada, por su alta peligrosidad. 
Otro milagro que se recoge es el concedido a Gabriel López, vecino de Pámanes, quien estando en la villa de la Guardia, enfermo de las piernas, y habiendo dispuesto los cirujanos cortarle una, después de pedírselo con fervor a Nuestra Señora del Soto, sanó enseguida de ambas. Para agradecerlo, peregrinó caminando sin dolores ni novedades durante tres días al Santuario de Iruz, donde publicó el favor recibido. Constan muchos favores más concedidos por aquella época. Baste ahora citar uno último, que ha sido muy celebrado. Se trata del sucedido a un pobre cautivo torancés que permanecía encarcelado en Argel por los moros, cargado de grillos y cadenas; por mediación de Nuestra Señora del Soto se vio milagrosamente liberado de ellos y transportado a su valle, trayendo consigo las cadenas, que en recuerdo y testimonio se colgaron en el camarín de la Virgen ${ }^{6}$.

La extraordinaria devoción a esta Virgen fue creciendo cada vez más. Prueba de ello son los numerosos testamentos del siglo XVI, redactados en la región y en América, donde aparecen mandas y donaciones para esta Virgen. Una muy significativa es la de la plata que mandara Francisco de Cevallos desde Guayaquil para la corona de la Virgen de Iruz, coronación que se realizó con toda solemnidad el 19 de abril de $1608^{7}$. Una copla popular muy antigua (recogida en González Echegaray, 1992, p. 98) cantaba esta preciosa estrofa:

\section{La Virgen del Soto, madre, es pequeñita y morena; nunca tuvo el Rey de España mejor soldado en la guerra...}

Toda esa época estuvo inmersa en el sueño de ultramar. En 1492 se había descubierto América, que enseguida se idealizó, asimilándola al reino de la bondad y donde cualquiera podía hacer fortuna. El entusiasmo creció aún más con la leyenda de "El Dorado", aquel codiciado lugar donde las calles se pavimentaban de oro, que fue buscado con gran empeño por los exploradores españoles e ingleses. Si bien es cierto que décadas más tarde el encanto comenzó a quebrarse, la idea de migrar hacia el continente de la esperanza sedujo los ánimos aventureros de los cántabros.

Como es de suponer, los viajeros que se enrumbaban a las nuevas tierras llevaron en el pecho los sentimientos religiosos que habían echado raíces desde su niñez. Entre esos, sin duda estaba la piadosa devoción a la Virgen de sus padres, de sus abuelos, a la Virgen del Soto. Por eso no es de extrañar que "los indianos" hayan enviado entonces

\footnotetext{
6 Sainz de los Terreros, quien recoge todos estos favores, anota de este último que "no constan particularidades del caso, conservado por tradición, ni se dice más que lo referido; pero es muy elocuente el hecho de existir aún dichas cadenas en el mencionado camarín" (1906, pp. 126-127).

7 Los detalles de la encomienda, del testamento y de los escribanos que intervinieron en ello constan espléndidamente narrados en Uría, 2005, pp. 142-147.
}

| 40 | REVISTA EÍDOS, diciembre 2014 desde América mandas de dinero o joyas, abundante platería en lámparas y vasos sagrados, para enriquecer el Santuario.

Con esas aportaciones y con las dadas por los lugareños más acaudalados para adquirir el derecho a ser enterrado en las capillas del templo, durante el siglo XVII y XVIII se fueron construyendo las diversas dependencias de la iglesia y del convento, y se elaboraron los diferentes retablos y objetos litúrgicos (cfr. Campuzano, 2004, pp. 35-36).

Tras la desamortización de 1836, el edificio fue abandonado, hasta que en 1899 se hicieron cargo de él los monjes carmelitas. Como era de esperarse, la imagen fue escondida durante la guerra civil que desgarró a España de 1936 a 1939. Al parecer, después fue quemada, por lo que se la reparó posteriormente, ya que solamente quedó el rostro estropeado. Pero fue restaurada la talla y la devoción volvió a nacer, con más fuerza aún. Hoy sigue siendo una de las más antiguas y devotas vírgenes de Cantabria. El día 6 de septiembre de 1959 fue coronada canónicamente Nuestra Señora del Soto como "Patrona del Valle de Toranzo", ante millares de romeros de toda Cantabria.

Las últimas restauraciones del convento recuperaron su brillante pasado y, desde el año 2004, el convento inauguró su nueva función como Casa Diocesana de Espiritualidad para servir de lugar de reflexión, retiro y convivencia de grupos religiosos que anhelen profundizar en la vida interior. La iglesia sigue abierta para recibir a los devotos de la Virgen del Soto que deseen acogerse a sus maternales cuidados.

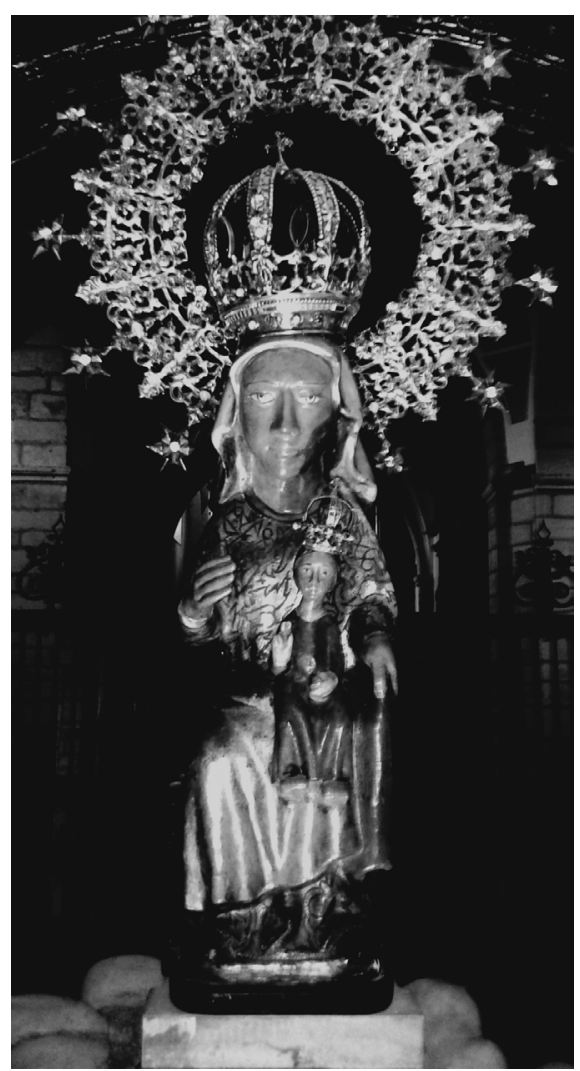

Figura $N^{\circ} 3$. Virgen actual. 


\section{LA VIRGEN DE IRUZ EN LA VIDA DE LOS CASTRO}

Sin lugar a dudas, el inicio en Guayaquil de la devoción de la Virgen del Soto-Iruz, que se tuvo por varios siglos, comenzó con la llegada de los Castro al pacífico puerto. Surgió sobre todo a partir del milagro que la Señora le hiciera a don Toribio Castro y Grijuela, por el que le restituyó una mano. Por eso los vecinos guayaquileños lo llamaron "Mano Santa".

La historia de los Castro en el valle de Toranzo se remonta a los abuelos de Mano Santa. Sus abuelos, Juan Castro y María de la Calleja, nacieron en 1474 y 1481, respectivamente, ambos en Cudón (Miengo, provincia de Santander, en la Cantabria de España). En su juventud migraron a Iruz, donde se casaron en el año 1500 y vivieron ahí el resto de sus días. Su primero y único hijo que conocemos fue Toribio Castro, que nació en 1503 en la misma comarca y casó con Toribia de Grijuela, de quien no poseemos muchos datos. Los Castro se caracterizaron por ser gente de principios, pues en la historia se verá que se les encomendaron puestos de responsabilidad y que gozaron de buena fama ${ }^{8}$. Resulta fácil pensar que habrán sido gente devota de la ya entonces célebre Virgen del Soto y que habrán peregrinado a su ermita para pedir por las necesidades de la familia.

Toribio trabó amistad con Rodrigo de Vargas Guzmán, natural de Torrejón de Velasco (Reino de Castilla), capitán

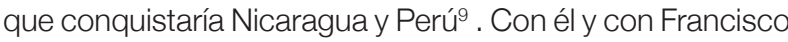
de Olmos, Toribio partirá para América a probar fortuna. Luego de varios años de campaña bélica, ellos se asentarán dentro del Virreinato de Nueva Castilla.

No sabemos cuántos hijos tuvieron Toribio y Toribia, ni cuándo se casaron. A juzgar por la edad, se habrán casado tarde para la época, pues de ellos nació en 1545 — cuando el padre había cumplido los 42 años — el único hijo que conocemos de este matrimonio: Toribio Castro y Grijuela Pudo ser su único hijo, y si lo fue, en él habrán cifrado todas sus esperanzas. ¡Cuán grande habrá sido el pesar de los padres cuando, después del parto, descubrieron que había nacido únicamente con la mano izquierda, teniendo solo un muñón en la derecha! ¡Cuánta aflicción y desconsuelo! Y también, jcuánta fe cuando la madre se sobrepuso a sus lágrimas y decidió peregrinar al Santuario de la Virgen de su juventud para pedirle que "le pusiera una mano" a su niño! Semejante petición no se entiende sin la enorme fe de doña Toribia, ni tampoco sin la difundida fama de la milagrosa imagen.

8 Como veremos, Toribio Castro participó en importantes gestas bélicas de la conquista, al lado de don Rodrigo de Vargas Guzmán.

9 Don Rodrigo de Vargas Guzmán fue capitán, conquistador, Gobernador de la Isla Puná, Alcalde Ordinario de Guayaquil en 1540, Teniente de Gobernador de Guayaquil en 1541 y, de 1547 a 1550, Encomendero de Yagual. Fue fundador de su linaje en el Ecuador. Casó en segundas nupcias con Mariana de Robles, que nació por 1520, sobrina del Dr. Francisco Pérez de Robles, Presidente de la Audiencia de Panamá. Cfr. Borrero, 1981, p. 61.
A la Virgen le agradó la plegaria de la madre, aunque, no obstante, quiso que la oración se afianzara con el tiempo ${ }^{10}$.

Por esos años la situación política en el Virreinato se había puesto muy tensa, desde que Francisco Pizarro fue asesinado en 1541. Entonces su hermano Gonzalo, que tenía un poder casi absoluto en Perú, se rebeló contra la Corona. Los bandos se dividieron en Nueva Castilla en pizarristas y realistas. Los leales al Rey armaron su ejército, que fue dirigido por el capitán Francisco de Olmos y contaba con el apoyo de los capitanes Rodrigo Vargas de Guzmán y Toribio de Castro. Tras meses de intrigas, se desencadenó la batalla que vio su fin el 6 de abril de 1547. Pizarro perdió y fue ajusticiado, con el Teniente Manuel de Estacio. Pero temiendo retaliaciones, los tres capitanes (Olmos, Vargas y Castro) construyeron grandes balsas y con 140 personas cruzaron el río Amay. El 25 de julio de 1547, día del apóstol Santiago, atracaron en lo que hoy es el barrio de "Las Peñas" y asentaron en la ciudad de la unión cimera de los cerros Santa Ana y el Carmen.

Toribia seguía estos acontecimientos de su esposo a la distancia, en Iruz, junto a su pequeño hijo, que ya para 1550 correteaba por la casa. Se dice que el niño destacaba por su generosidad. Un buen día, cuando el pequeño tenía 5 años de edad (cfr. Aspiazu, 1955, p. 249), alguien se acercó a la puerta: era un mendigo que pedía un pan. La madre estaba atareada en las cosas de la cocina y solo se percató de que su hijo entró a coger un pedazo de pan, que regresó a la puerta y se lo dio. Al volver su niño, con asombro la madre observó que donde antes había un muñón, ahora había una bella mano. Ella exultó en agradecimientos y loas a la Virgen santísima que al fin había escuchado su perseverante oración. Enseguida se enteró el resto de la familia y toda la comarca, que se unió devota a su acción de gracias. Como recuerdo, al niño le quedó, a manera de pulsera que nunca se le borró, una línea roja en la muñeca de la mano. (cfr. Pimentel, 2001b).

\section{EL ARRIBO DE LA DEVOCIÓN A LAS COSTAS ECUATORIANAS}

El niño creció en edad, en fama y en las virtudes que le inculcó su devota familia. Al cabo del tiempo, Toribia y Toribio se reunieron de nuevo en Guayaquil, donde ya se radicaron junto a su querido hijo. En el puerto, el padre había trabado gran amistad con los principales de la ciudad, como lo eran Francisco Olmos y Rodrigo Vargas Guzmán, quien contaba con la fama de haber sido uno de los descubridores de Nicaragua y Perú. Desde entonces, la historia de Mano Santa quedará ligada a la figura de este gran conquistador.

10 La historia ha sido narrada por varios de los autores citados en la referencia. En parte seguimos aquí el relato de Pino Roca (1930), precisando fechas, lugares y personajes en lo que nos resulta posible. 
Mano Santa casó con la hija del conquistador don Rodrigo de Guzmán y de Vargas el año 1565, cuando él tenía veinte años y ella veintidós. Leonor Guzmán y Vargas era de Valdemoro, España, pero habrá llegado a Guayaquil para vivir con su padre por la misma época en que Mano Santa arribó a América ${ }^{11}$. En estas tierras surgió el amor. La diferencia de edad no mermó la felicidad del matrimonio, que dio a luz a siete hijos: José, Toribio (†1640), Micaela (†1633), Magdalena, Leonor (†1667), Catalina y María.

Como dijimos, don Rodrigo había sido uno de los vecinos fundadores de Guayaquil, ciudad en la que luego ejerció importantes cargos. Había sido Alcalde Ordinario del Cabildo en 1540 y Teniente de Gobernador en 1541, y también lo fue de 1547 a 1550. Habiendo hecho tantas amistades y habiéndole tomado el gusto a la vida porteña, decidió radicarse definitivamente en estas tierras, hasta su muerte, junto a su esposa doña Mariana de Robles. Aquí, en 1561, se desempeñó como Encomendero de Yagual, por merced otorgada por el Marqués Pizarro, con una renta de 1150 pesos; dejó la encomienda, pero se la volvió a otorgar el Marqués de Cañete (Hampe, 1979, p. 113). También fue Gobernador de la Isla Puná.

Mano Santa supo estar a la sombra de tan importante trayectoria de su suegro. Consta que el 24 de marzo de 1572, en esta ciudad, don Rodrigo otorgó e "hizo probanza de servicios y méritos por ser uno de los primeros descubridores y conquistadores de Nicaragua que después vino al Perú con Pedro de Alvarado" (AGl, Patronato 118, R 8). Y fue ese mismo año de 1572, seguramente por sus recomendaciones, que don Toribio de Castro y Grijuela (Mano Santa) se posesionó como Corregidor y Teniente General de la Provincia.

Además, las buenas relaciones que don Rodrigo mantuviera con los puneños le granjearon la amistad con Diego Tomalá, quien en la Isla producía y negociaba sal desde el tiempo de los incas ${ }^{12}$. Mano Santa vio la oportunidad de negociar con Tomalá, y el 15 de enero de 1577 le arrendó las salinas obteniendo un gran poder en el mercado guayaquileño de este producto. Los ingresos le permitieron adquirir terrenos en Punta Arenas y entrar en el negocio naval creando el Astillero Real de Guayaquil. Además, luego consiguió hacerse cargo de la Encomienda de los Indios de Santa Elena. La familia fundada por Toribio Castro y Grijuela llegó a ser la más poderosa de la zona. Por alguna razón la Virgen quería o permitía que a su niño le fuera bien en los

11 Es decir, después de 1550 (fecha del milagro) y antes de 1565. Consta que la hija María Castro nació en Guayaquil alrededor de 1568 (no se tienen datos de la fecha de su fallecimiento). Por tanto, no parece cierto que Toribio pasó a Guayaquil hacia 1572, como se ha dicho.

12 Según Valencia Salas, "Tomalá gozaba desde el tiempo de los incas del monopolio de la sal y su comercio. Después de la conquista española, el Virrey don Andrés Hurtado de Mendoza reconoció este beneficio mediante provisión del 27 de mayo de 1560. Dieciséis años más tarde, el Virrey Francisco de Toledo ratificó la concesión, el 6 de diciembre de 1676, declarando que el Cacique de la Puná aprovechaba desde tiempo inmemorial de las salinas de la isla" (Valencia, 1994, p. 59). Cfr. Vargas, 1981, pp. 101-103; Salazar de Villasante, 1992, pp. 59-60. negocios.

Otro hecho significativo de la vida de Mano Santa se dio en 1587, durante la invasión que intentó perpetrar Thomas Cavendish en el Golfo ${ }^{13}$. El año anterior, el inglés había obtenido una Real Patente de Corso de manos de Isabel de Inglaterra, con la que inició en Plymounth un viaje alrededor del mundo y donde obtuvo pingües ganancias con el pillaje en las costas. Con posibles intenciones de asaltar Guayaquil, Cavendish desembarcó en la isla Puná, para hacerle frente al Cacique Tumbalá. Entonces las defensas porteñas eran bastante exiguas, pues no se contaba con artillería para enfrentar al pirata. Sin perjuicio de ello, el 12 de junio de $1587^{14}$ el Corregidor de Guayaquil, don Jerónimo de Reinoso y Piedrola, junto a la gente de Mano Santa ${ }^{15}$ que aportó con las embarcaciones y contando con la ayuda del cacique Tomalá, asaltaron el campamento corsario y dieron muerte a veinte enemigos ${ }^{16}$ y obligaron a Cavendish a escapar a alta mar. Unos pocos no pudieron embarcarse y con ellos siguió el combate, hasta que vieron arder la casa donde se refugiaban y tuvieron que rendirse, acosados por el fuego. Los Castro y Grijuela defendieron así las propiedades y negocios que tenían en la Isla.

Una leyenda cuenta que en cierta invasión pirata salió Mano Santa a defender la ciudad, y que de sus manos brotaron rayos que neutralizaron al enemigo (Pino Roca, 1930). Parece más legendario el hecho de los rayos, aunque quizá pueda rescatarse un pequeño núcleo de verdad de las dos historias antes narradas. En el fondo consta que la Virgen de la Mano Santa era considerada por el pueblo como oportuna y eficaz protectora de la Muy Noble y Leal Ciudad de Santiago de Guayaquil.

Cada día que se levantaba Toribio veía una línea en su mano que atestiguaba el notorio cariño que la Virgen había tenido con él. Además se daba cuenta de que, a sus casi cuarenta años había realizado una carrera insigne, había hecho dinero, había logrado una familia feliz. Seguramente se habrá preguntado en varias ocasiones, a lo largo de su vida, por qué tantos favores recaían en su persona, por qué la Virgen se mostraba tan misericordiosa con él. Sea por respuesta a estas inquietudes, sea porque entonces se empezó a dudar del milagro que el cielo había obrado

13 Cavendish nació en Trimley St. Martín, Suffolk, Inglaterra, el año 1560. Realizó estudios en Cambridge, pero habiendo perdido todo su patrimonio se entregó por completo al pillaje por mar. En 1586, luego de obtener una Real Patente de Corso de manos de Isabel de Inglaterra, inició en Plymounth un viaje alrededor del mundo. Fue el primer corsario que se aventuró a llegar a nuestras costas. Cfr. Johnstone, 1910; Cavendish, 1975.

14 A veces se pone la fecha en 1584 o en 1591. Consta que Cavendish abandonó el puerto Plymouth el 22 de julio de 1586 con tres naves llamadas Desiré, Gontení y Hugh Gallant, y que el 24 de febrero de 1587 recorre las costas chilenas hasta llegar a Arica, donde fue rechazado por un grupo de bravas mujeres. De ahí subió hasta la Puna. Cfr. Hoyos, 2008, pags. 51-52.

15 En concreto, fueron sus hijos Toribio y José los que, al frente de varios de sus trabajadores, enfrentaron la invasión. Pino Roca incluye a Mano Santa, quien para 1587 contaba con 43 años. La mayoría de autores coinciden en que sólo financió la expedición.

16 Pino Roca (1930) y González Suárez (1890) concuerdan en el número de muertos: seis guayaquileños y veinte corsarios. Pino Roca, además, añade que nueve guayaquileños y siete enemigos quedaron heridos. Hoyos (2008, p. 54) analiza y acepta los números. 
en sus miembros, lo cierto es que, en 1584, se decidió a viajar a su ciudad de origen para conseguir pruebas que certificaran la veracidad de la restitución de su mano. El 10 de marzo de 1584 Toribio acudió con cuarenta testigos al Escribano Público del Valle de Toranzo, para certificar lo que ellos habían visto. Con ese certificado regresó a las costas pacíficas, para exhibirlo a cuanto incrédulo apareciera ${ }^{17}$.

Pero Mano Santa aún le daba vueltas a su razón de ser en la vida y, al ser tan devoto a la Virgen de su mano, a la Virgen de sus padres, a la Virgen de sus abuelos, a la Virgen del pueblo que lo vio nacer, decidió traerla. Estaba muy lejos, en Iruz, y tenía que estar muy cerca de él, y con él permanecer para siempre. Por eso no dudó en hacer gestiones para que, en 1583, los agustinos arribaran a Guayaquil, debidamente financiado el viaje y la construcción de su Convento de Ermitaños por él y su familia ${ }^{18}$. Pero, sobre todo, lo que le movía era construirles el templo que llevó por nombre "Capilla de Nuestra Señora del Soto", en 1594. En el altar mayor, que fue tallado en madera por artífices del puerto, se puso un lienzo al óleo con la imagen milagrosa de la Virgen del Soto, circundada con una aureola y con el divino Niño en sus brazos; a los pies de la imagen y, casi al extremo de la tela, figuraba otro niño al que faltaba el brazo derecho. Desde entonces se veneró en Guayaquil a esta muy antigua, muy querida y siempre amada Virgen.

A continuación se sucedieron algunos hechos amargos en la vida de Mano Santa. Ya varios hijos suyos habían muerto. Ahora era la salud de su esposa, doña Leonor de Guzmán, la que comenzó a resquebrajarse, hasta que un día entregó el alma al Creador. Se dice que los hombres que han sido felices en el matrimonio, cuando enviudan tienden a casarse de nuevo, y fue esto lo que sucedió con Toribio. Al cabo del tiempo encontró a María de Castañeda, con quien contrajo nupcias y quien le acompañó en Guayaquil hasta el final de sus días ${ }^{19}$.

La historia del milagro de la restitución volvió a ponerse en tela de duda en estos lares, y fue preciso que don Toribio Castro y Grijuela hiciera nuevas gestiones para certificarlo. El 24 de mayo de 1608, el Escribano Real de Iruz, Francisco

17 Según Pérez Pimentel (2001b, voz "Antonio Bastidas y Carranza"), tales certificados estaban en poder de las hijas solteras del Presidente Diego Noboa Arteta, último poseedor del Vínculo o Mayorazgo de las salinas de Punta Arenas, pero se quemaron en el Incendio del Carmen de 1902. En Cantabria, muchos de estos documentos fueron quemados durante la Guerra Civil española. No pude encontrarlos en el breve viaje que hice a Iruz en marzo de 2013

18 Consta que la familia Castro tuvo suficientes recursos para tal obra porque se dedicó al lucrativo negocio de construir barcos para la corona y para su propia empresa. Comerciaban con España y con el Lejano Oriente. Toribio de Castro hijo llegó en 1612 a cubrir el puesto de asistente de Beaumonte, superintendente de los astilleros. Los barcos de entre 600 y 1000 toneladas costaban al menos 125000 pesos en 1640 y 200000 pesos en 1670 (cfr. Clayton, 1980, pp. 230-233). En el asalto de 1624 los piratas le quemaron a los hijos Toribio de Castro Guzmán y José Antonio de Castro Guzmán un galeón que valía más de 75000 pesos (cfr. Aspiazu, 1955, p. 249)

19 Este segundo matrimonio consta en el testamento que Toribio Castro y Grijuela hizo en Guayaquil ante el escribano Miguel Jerónimo de Bastidas, el 22 de marzo de 1609, donde expresa que, viudo de Leonor de Guzmán, volvió a casar con María de Castañeda. No suele recogerse este dato en otros documentos históricos.
Gómez, nuevamente juntó decenas de testigos, diferentes a los primeros, que acreditaron la verdad de los hechos ocurridos.

En el ocaso de sus días, Mano Santa redactó un testamento en Guayaquil ante el escribano público, Miguel Jerónimo de Bastidas, el 22 de marzo de 1609. En él instituyó el vínculo y la obra pía de 4200 pesos de a 9 reales, sobre sus casas y demás bienes de Punta Arenas (casas y salinas con pozos y albarradas ubicadas en la isla Puná, frente a Santa Clara ${ }^{20}$. Tales bienes se destinaban para remedio de las hembras para sus dotes de casamiento. Designó como patronos a vita a sus hijos legítimos José y Toribio, después a sus dos hijas legítimas mayores y luego a sus descendientes, señalándoles una renta del 10\% por la administración de los bienes ${ }^{21}$

Poco después, Mano Santa habrá partido de este mundo para ver a la Señora que tantos favores le hizo en vida. El pueblo mitificará su figura ${ }^{22}$ y sus hijos darán continuidad a esa devoción que empezó en su padre, que empezó en sus abuelos, que empezó en sus bisabuelos, que empezó allá por el siglo XIII. La Virgen llegó a Guayaquil para quedarse.

\section{LA DEVOCIÓN SECULAR DE LA IMAGEN}

Como dijimos, la talla de la Virgen del Soto es una de las más antiguas y veneradas imágenes de Cantabria. El culto allá no ha cesado con el paso de los siglos, sino que se ha incrementado. Algo parecido ha sucedido por estos lares.

Desde que en 1594 se construyera la Capilla de Nuestra Señora del Soto, con los donativos de la familia Castro y Grijuela, el fervor se ha mantenido. El mencionado templo estaba situado en los límites de la actual iglesia de Santo Domingo, cerca de un estero de río que había que atravesar por un puente de maderos y caña. Según Pérez Pimentel, el templo "era de naturaleza precaria, de una nave de ancho, techo de hojas de bijao entrelazadas con lianas, los puntales de guayacán y amarillo y las rústicas paredes de caña. No era bonito pero nuestros antepasados llegaron a apreciarlo mucho" (Pérez Pimentel, 2001a, voz "Ermitaños de San Agustín"). El lienzo que escenificaba a la Virgen del Soto y a

20 En 1609 Toribio de Castro y Grijuela instituyó el tercer mayorazgo, de los siete que habría en la Audiencia de Quito hasta 1700. Cfr. Ponce, 1996, p. 344; Valencia, 1994, pp. 119-120.

21 El Testamento y fundación de Toribio de Castro y Grijuela consta en las Actas del Cabildo de Guayaquil 1634-1639, folio Ayer F 3791.G9 A35. Cfr. Anuario histórico jurídico ecuatoriano, vol.1, pp. 487-499.

22 Por ejemplo, se ha dicho que la Virgen le regaló "una mano que no era común ni de carne y hueso, era de coloración negra y poseía grandes habilidades. El chico no solo pasó de ser derecho a zurdo, sino que con ella incluso logró vencer en un duelo de espadas al pirata Thomas Cavendish, a quien además le dejó marcados sus cinco dedos en el pecho, cuando la mano se tornó incandescente" (Diario Expreso, 2013, Marzo 31). También "Se dice que cuando su cuerpo fue exhumado, algunos años después de su muerte, su mano, su prodigiosa mano negra no se había corrompido ni se había descompuesto, razón por la cual los guayaquileños la colocaron en una urna de vidrio, al pie de la imagen de la Virgen del Soto, que se conservaba en la iglesia de Santo Domingo" (Diario Expreso, 2013, Septiembre 14). 
Mano Santa sufrió los años, los inviernos, la invasión pirata de 1624, perpetrada por el holandés Jacob L'Hermite, y aun así, tras numerosos remiendos y empastes, perduró en Guayaquil, en una de las paredes de la sacristía del templo.

El culto que se tributaba en San Agustín a Nuestra Señora del Soto siguió afianzándose en el pueblo guayaquileño durante los siglos XVII a XIX ${ }^{23}$. Se tiene noticia de varias donaciones que los devotos realizaron al "Real Convento de Nuestra Señora del Soto"24.

Sin embargo el incendio de 1902, que asoló 26 manzanas de la ciudad, con unas 700 casas, y que dejó a la intemperie a más de quince mil personas, también terminó devorando este querido y venerado cuadro de la Virgen. Como se dijo, el cuadro se encontraba en la antigua iglesia levantada en el cerro del Carmen, en medio de aquella "Ciudad Vieja" que había sobrevivido tres siglos. La Ciudad Vieja había sido muy mermada con el incendio de 1896, pero desapareció absolutamente con el fuego del año 1902.

El pueblo porteño pasó más de medio siglo con el vacío de no tener una Virgen propia a la que acudir, que intentó suplirse de alguna manera. El acto más significativo fue el de la presentación del cuadro "Santa María, Madre de Guayaquil” pintado por Arturo Guerrero, que se realizó en el centro de convenciones Simón Bolívar, el 18 de mayo de 2011, en presencia de obispos y vicarios de la Arquidiócesis de Guayaquil. Desde luego, esa oportunísima iniciativa no "compite", ni va en desmedro de las múltiples devociones marianas que puede tener una ciudad. Piénsese, por ejemplo, en las diversas Vírgenes "de Quito": la Virgen alada, la de la Merced, la del Buen Suceso..., cuya variedad es fiel muestra de la intensa piedad mariana de esta sociedad.

El cuadro de Mano Santa y la devoción a esta Virgen tuvieron el mismo final que la Ciudad Vieja, pero con ella también tuvieron el mismo resurgir. En las últimas décadas del siglo XX brotará, cada vez con más fuerza, la aspiración de recuperar el Guayaquil perdido, la Ciudad Vieja, el pueblo olvidado... Primero serán los historiadores los que rastreen las pistas del pasado, luego los arqueólogos, luego los museos, seguidos por la gente dedicada a la cultura, al arte, a la literatura... Los arquitectos volverán a parar la Casa Rosada que ya estaba caída, así como otros derruidos edificios, y en el sur de la Ciudad volverá a nacer una tierna devoción a la muy antigua y nunca olvidada Virgen de Guayaquil.

23 Algún dato de ella lo recoge Ponce Leiva (1992, t. II, p. 23) quien observa que en la ciudad de aquel tiempo había 4 templos: "el parroquial, que se llama Iglesia mayor, y su advocación es Santiago, y 3 en los 3 conventos de frailes: el de San Pablo, en Santo Domingo; el de Nuestra Señora del Soto, en San Agustín, y el de San Francisco, en su convento".

24 Por ejemplo, Pérez Pimentel comenta de Jacinto de Bejarano y Lavayen (c. 1752-1820), de quien se dice que "era su costumbre socorrer a los pobres y entregar limosnas para el culto divino, daba 8 pesos mensuales a "Real Convento de Nuestra Señora del Soto" y era miembro de la Cofradía de las Ánimas, de la Iglesia de San Agustín" (2001b).
Para alegría de muchos vecinos, en 1963 se levantó un templo dedicado exclusivamente a Nuestra Señora del Soto al sur de la ciudad ${ }^{25}$, en los terrenos donados por don Pedro de Robles. El artista de la estatua, que tiene las dimensiones reales de un cuerpo humano, no tomó en cuenta - seguramente por desconocimiento- los rasgos de la Virgen de Iruz, pero sí recogió en una nueva expresión artística los conceptos esenciales de la Mano Santa. La tez de los personajes es blanca, muy blanca, de tiernos gestos. Tanto la madre como el Niño levantan su brazo derecho bendiciendo la humanidad, de forma cercana a la talla de Iruz, pero he aquí que al Niño le falta la mano izquierda ${ }^{26}$. En el barrio se considera que este hecho refleja bien cómo el Hijo ha querido cargar con nuestros defectos, males y dolores, para redimirlos asociando a esta misión a su Madre Santísima.

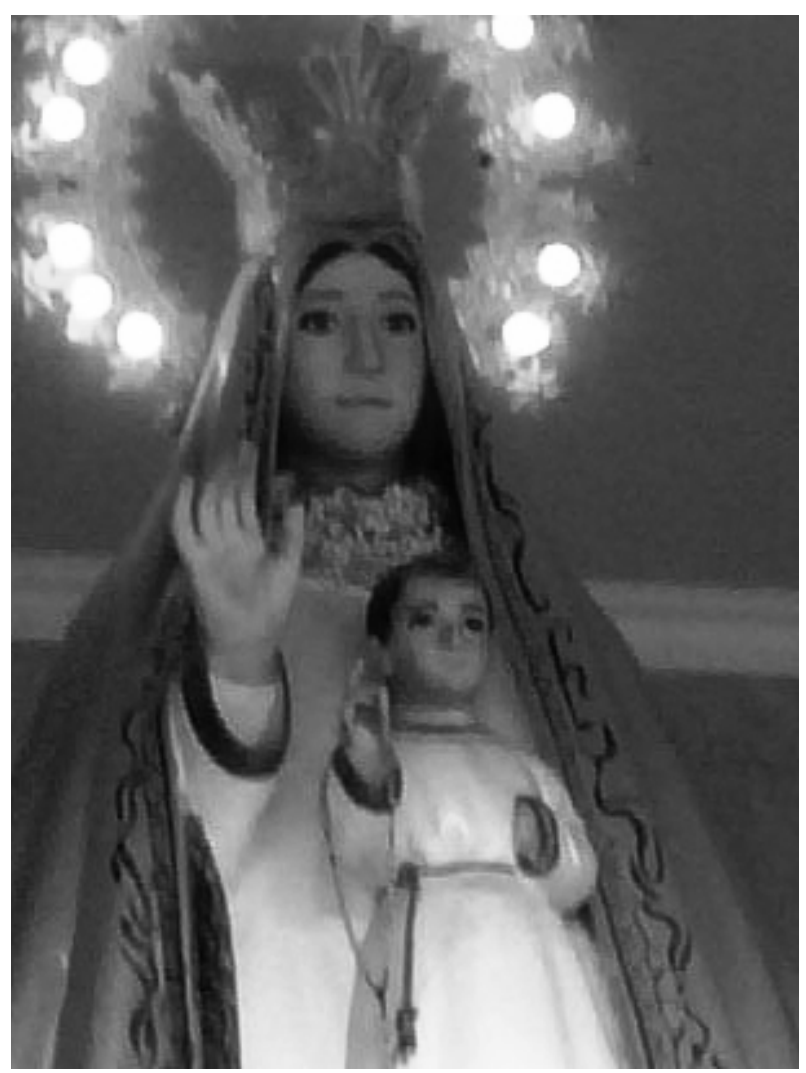

Figura $N^{\circ} 4$. Virgen de la parroquia.

El templo actual de Nuestra Señora del Sur de Guayaquil es cada vez más concurrido, especialmente en Semana Santa, cuando traen el Cristo del Consuelo, que viene desde la iglesia vecina (ubicada en Lizardo García y la A), seguido por miles de fieles. En tales ocasiones alguna gente pasa toda la noche en vigilia, a los pies de la Virgen de la Mano Santa y de su Cristo ${ }^{27}$.

25 La Capilla está ubicada en la D, entre Nicolás Segovia y Guerrero Martínez. El barrio ha tomado el nombre de "Ciudadela Virgen del Soto". 26 El autor se refiere al Niño Jesús, no al Niño Mano-Santa (nota del editor).

27 Cfr. los testimonios de los fieles recogidos en el diario El Universo, el 8 de abril de 2007 y el 24 de abril de 2011. 
Actualmente, el artista londinense Dominic Maffia ha pintado un cuadro de 1,9 metros de altura por 1,2 metros de ancho, con el objetivo de rescatar la vieja devoción. Lo ha hecho utilizando técnicas de pintura e imágenes de la época. Además, ha añadido al cuadro muchos elementos simbólicos, que convendrá analizar con más detalle en otro estudio. Esta imagen será colocada en la Iglesia del cerro Santa Ana, donde antiguamente colgó el viejo cuadro de la Virgen de la Mano Santa.

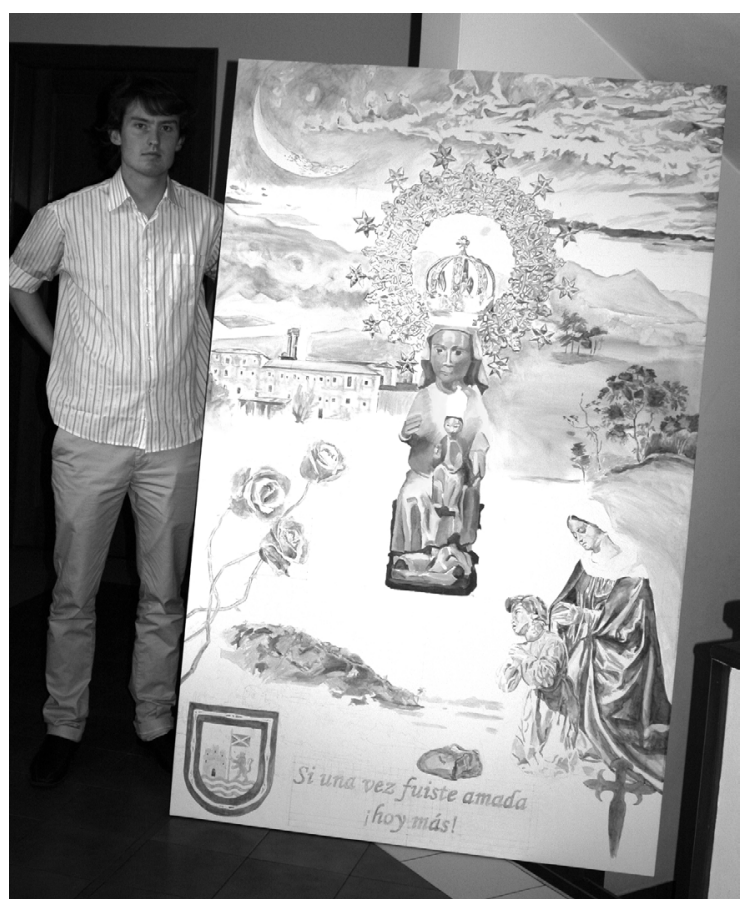

Figura № 5. Pintor y cuadro.

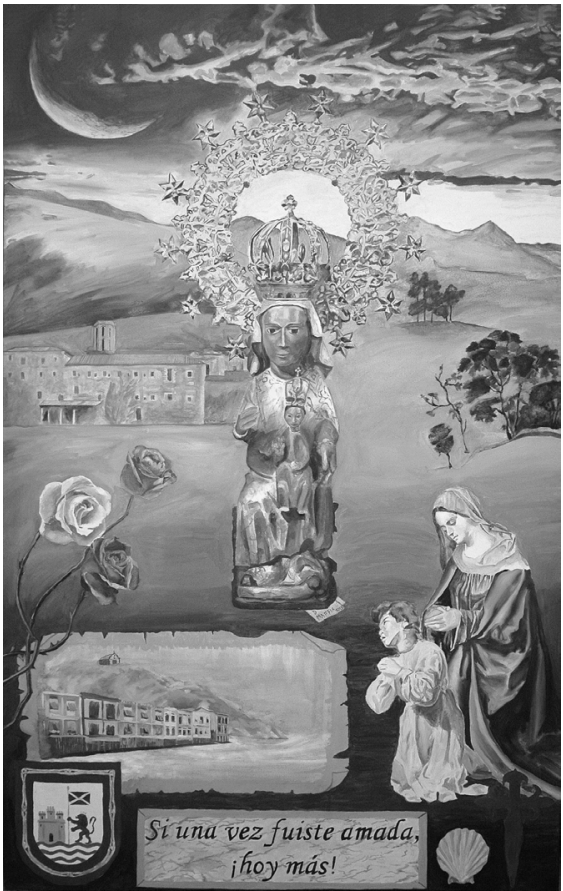

Figura $N^{\circ}$ 6. Cuadro

\section{CONCLUSIONES}

Guayaquil ha tenido una devoción mariana propia, desde su misma fundación. La Virgen del Soto ha acompañado la vida de los primeros moradores de Guayaquil y las generaciones sucesivas. Venía ya en el alma de Toribio Castro el 25 de julio de 1547 cuando atracaron con los primeros colonos del puerto por el barrio de las Peñas; en esos momentos él y su esposa Toribia rezaban constantemente a esta Virgen por la mano de su Niño. Años más tarde llegó en persona al puerto, el milagro de la Mano Santa. Los Castro y Grijuela financiaron, además, la venida de los agustinos y la construcción del templo a su Virgen amada, la misma que se veneró de forma ininterrumpida por tres siglos, hasta que en 1902 el fuego se llevó todo recuerdo. El pueblo porteño pasó más de medio siglo con el vacío de no tener una Virgen propia a la que acudir, lo cual intentó suplirse de alguna manera. Pero la devoción que una vez nació, hoy se niega a morir: hoy el antiguo cuadro se vuelve a rescatar.

\section{REFERENCIAS BIBLIOGRÁFICAS}

Aspiazu, M. (1955). Las fundaciones de Santiago de Guayaquil. Guayaquil: Casa de la Cultura Ecuatoriana.

Borrero Crespo, M. (1981). Orígenes Cuencanos. CENIGA 3.

Cabildo de Guayaquil. (1970). Actas del Cabildo de Guayaquil 1634-1639. Anuario Histórico Jurídico Ecuatoriano. Guayaquil: Corporación de Estudios y Publicaciones.

Campos, J.A. (1999). Historia documentada de la Provincia del Guayas. Guayaquil: Municipio de Guayaquil.

Campuzano, E. (2004). El Convento del Soto. Revista de Cantabria, octubre-diciembre, pp. 34-40.

Cavendish, T. (1975). The last voyage of Thomas Cavendish. Chicago: Univ. of Chicago Pr.

Clayton, L.A. (1980). Caulkers and Carpenters in a New World: The Shipyards of Colonial Guayaquil. Latin America Series, 8. Athens (Ohio): Ohio UniversityCenter for International Studies, pp. 88-94.

Cooper, J. C. (1988). El simbolismo. Buenos Aires: Lidium. González Echegaray, M.C. (1992). María en los pueblos de España. Guía para visitar los santuarios marianos de Cantabria. Madrid: Encuentro.

González Suárez, F. (1890-1903). Historia general de la República del Ecuador. Quito: Imprenta del clero.

Guayaquil, Redacción. (2013, marzo 31). 7 de los templos más antiguos seducen con sus historias. Guayaquil: Diario Expreso, sección Semana. Recuperado de http://www.semana.ec/ediciones/2013/03/31/ destinos/destinos/7-de-los-templos-masantiguos-seducen-con-sus-historias/ (accedido el 13/11/2014). 
Guayaquil, Redacción. (2013, septiembre 14). Milagro de una mano que sobrevivió. Guayaquil: Diario Expreso. Recuperado de http://expreso.ec/expreso/plantillas/ nota. aspx ?idart $=5079247 \&$ idcat $=19351 \&$ tipo $=2$ (accedido el 13/11/2014).

Hampe Martínez, T. (1979). Relación de los encomenderos y repartimientos del Perú en 1561. Historia y Cultura 12.

Hoyos Galarza, M. (2008). Los recuerdos de la iguana: historias del Guayaquil que se fue. Guayaquil: Municipio de Guayaquil.

Johnstone, C.I. (1910). Sir Francis Drake, Thomas Cavendish, William Dampier. New York: Werner Co.

Pérez Pimentel, R. (2001a). El Ecuador profundo, t. I. Guayaquil: Junta de Beneficencia de Guayaquil.

Pérez Pimentel, R. (2001b). Diccionario Biográfico del Ecuador. Guayaquil: Universidad de Guayaquil.

Pino Roca, J.G. (1930). Leyendas, tradiciones y páginas de historia de Guayaquil. Guayaquil: Ed. Jouvin.

Ponce Leiva, P. (1992). Relaciones de la Audiencia de Quito, tomo II. Madrid: CSIC.

Ponce Leiva, P. (1996). Élite local y Cabildo de Quito, siglo XVII. (Tesis doctoral). Madrid: Universidad Complutense de Madrid. Recuperada de la base de datos de la misma Universidad que consta en http:// eprints.ucm.es/2452/ (accedido el 13/11/2014).

Sainz de los Terreros, M. (1906). Breve reseña de los Santuarios Marianos en la Provincia de Santander. Madrid: Tip. Sucesores de Rivadeneyra.

Salazar de Villasante, J. (1992). Relación general de las poblaciones españolas del Perú-1568. Relaciones histórico-geográficas de la Audiencia de Quito (Siglo XVI-XIX), Ed. Pilar Ponce Leiva. Quito: MARKAEdiciones Abya Yala.

Uría Maqua, J. (2005). Alonso de Bello (1552-1632): Un indiano perulero de los siglos XVI y XVII. Oviedo: Universidad de Oviedo.

Valencia Sala, G. (1994). Mayorazgo en la Audiencia de Quito. Quito: Abya-Yala.

Vargas, J.M. (1981). La Economía Política del Ecuador. Quito: Banco Central del Ecuador. 